\title{
PENGARUH MODEL PEMBELAJARAN INKUIRI TERHADAP HASIL BELAJAR SISWA PADA MATERI POKOK GETARAN DAN GELOMBANG DI KELAS VIII SMP NEGERI 1 LIMA PULUH T.P 2013/2014
}

\author{
Ida Wahyuni dan Haris Samosir \\ Ida.wahyuni94@yahoo.co.id \\ Jurusan Fisika FMIPA Universitas Negeri Medan \\ Jalan Willem Iskandar Pasar V Medan, 20221
}

\begin{abstract}
This study aimed to know the effect of model inqury for the learning outcomes of students in the subject matter vibrations and waves in the eighth grade $2^{\text {nd }}$ semester of SMP Negeri 1 Lima Puluh T.P. 2013/2014. The study population was all student of class VIII SMP Negeri 1 Lima Puluh consists of seven classes and the sample consists of two classes, specifically control class and experimental class taken by cluster random sampling. The author had applied model inqury in the experimental class and convensional model in the control class. The study instrument used was a essay test. Postest results of experimental class is 66.80 and the control class is 45.43. Students activity at the time of implementation of model inqury has increased from $50.29 \%$ (enough active) at $1^{\text {st }}$ meeting, $69.61 \%$ (active) at $2^{\text {nd }}$ meeting and became $90.22 \%$ (very active) at $3^{\text {rd }}$ meeting. The result indicates the learning outcomes of students using inqury model is higher than using convensional model.
\end{abstract}

Keywords: Activities, Learning Outcomes, Inqury.

\section{PENDAHULUAN}

Pendidikan adalah suatu proses pembaharuan makna pengalaman, hal ini mungkin akan terjadi di dalam pergaulan biasa atau pergaulan orang dewasa dengan orang muda, mungkin pula terjadi secara sengaja dan dilembagakan untuk menghasilkan kesinambungan sosial. Proses ini melibatkan pengawasan dan perkembangan dari orang yang belum dewasa dan kelompok dimana dia hidup (dalam Joyce :1996).

Dari pelaksanaan PPL (Program Pengalaman Lapangan) di SMP Negeri 1 Lima Puluh, kemampuan siswa tergolong rendah.
Hal ini dapat dilihat dari nilai harian siswa yang mayoritas tidak lulus (KKM) kriteria ketuntasan minimum.

Dari hasil wawancara dengan salah satu guru IPA di SMP Negeri 1 Lima Puluh, Pembelajaran sains fisika sering dipandang sebagai salah satu ilmu yang abstrak disajikan dalam bentuk teori yang kurang menarik dan terkesan sulit, menganggap bahwa fisika itu begitu susah dipahami dan dikuasai. pembelajaran fisika merupakan tujuan untuk memecahkan masalah yang dihadapi siswa agar memiliki pandangan yang lebih luas dan mempunyai sikap menghargai 
kegunaan fisika sebagai bagian dari ilmu pengetahuan alam dan teknologi.

Rendahnya pencapaian hasil belajar siswa menunjukkan bahwa pembelajaran yang dilakukan selama ini belum sesuai dengan tujuan. Menyikapi masalah di atas, perlu adanya usaha-usaha guru dalam meningkatkan pemahaman siswa tentang konsep-konsep fisika yang disampaikan guru, sehingga tujuan pembelajaran yang telah direncanakan bisa tercapai dan dengan demikian hasil belajar juga meningkat.

Guru harus memilih model pembelajaran yang sesuai dengan tujuan pembelajaran dan mendesain proses pembelajaran dengan baik agar siswa lebih tertarik belajar di dalam kelas dan mengulang kembali pelajarannya di rumah. Salah satu model pembelajaran yang dapat dilakukan oleh guru adalah dengan menerapkan model pembelajaran Inkuiri. Model pembelajaran inkuiri adalah rangkaian kegiatan pembelajaran yang menekankan pada proses berpikir secara kritis dan analitis untuk mencari dan menemukan sendiri jawaban dari suatu masalah yang dipertanyakan. Karakteristik dari model inkuiri ini adalah guru tidak mengkomunikasikan pengetahuan, tetapi membantu siswa untuk belajar bagi mereka sendiri, kemudian topik, masalah yang dipelajari, dan metode yang digunakan untuk menjawab permasalahan dapat ditentukan oleh siswa, dapat ditentukan oleh guru, dan dapat ditentukan bersama oleh siswa dan guru. Pembelajaran inkuiri memberi tekanan pada ideide konstruktivis dari belajar. Kemajuan belajar terbaik terjadi dalam situasi kelompok.
Model pembelajaran ini telah diterapkan dalam penelitian sebelumnya oleh beberapa mahasiswa, di antaranya adalah: harahap, (2009), mengatakan bahwa: " Ada pengaruh Model Pembelajaran Inquiry Training Terhadap Hasil Belajar Siswa.Sirait (2010) menunjukkan bahwa : hasil belajar siswa dengan menggunakan model pembelajaran inquiry training memiliki rata-rata 6,29 dan hasil belajar siswa kelas dengan menggunakan model pembelajaran konvensional memiliki rata-rata 5,64. Kelemahan dari peneliti di atas adalah ketidakmampuan peneliti mempersiapkan permasalahan yang mengunggah rasa ingin tahu siswa sehingga termotivasi menemukan jawaban permasalahan, akibatnya siswa tidak kondusif dalam mengikuti pembelajaran. Kemudian peneliti terdahulu belum menggunakan keterampilan berpikir, oleh sebab itu yang membedakan peneliti dengan penelitian sebelumnya terletak pada tahaptahap inquiry. Peneliti merancang tahap-tahap dengan sangat menarik sesuai dengan kemampuan awal siswa sehingga pelaksanaan belajar mengajar menjadi efektif dan siswa kondusif.

\section{Model Pembelajaran Inkuiri}

Inkuiri adalah

pembelajaran didasarkan pada pencarian dan penemuan melalui proses berfikir secara sistematis. Pengetahuan bukanlah sejumlah fakta hasil dari mengingat, akan tetapi hasil dari proses menemukan sendiri. Dengan demikian dalam proses perencanaan, guru bukanlah mempersiapkan sejumlah materi yang harus dihafal, akan tetapi merancang pembelajaran yang 
memungkinkan siswa dapat menemukan sendiri materi yang harus dipahaminya. Belajar pada dasarnya merupakan proses mental seseorang yang tidak terjadi secara mekanis. Gulo menyatakan bahwa discovery merupakan bagian dari inquiry, atau inqury merupakan perluasan proses discovery yang digunakan lebih mendalam.

Model Inkuiri dimulai dengan menyajikan situasi yang penuh pertanyaan. Dengan situasi yang penuh teka-teki secara alami siswa akan terdorong untuk memecahkan teka-teki itu. Pengkondisian lingkungan belajar melalui cara tersebut mendorong siswa meningkatkan intensitas kesadaran akan proses penelitian yang dilakukan pada saat itu secara langsung dapat diajarkan cara melakukan prosedur penelitian yang bersifat ilmiah.

Menurut Moh Uzer Usman model pengajaran inkuiri memiliki tujuan dan manfaat dalam peningkatan kreativitas belajar siswa, diantaranya adalah : mengembangkankemampuan dan keterampilan dalam memecahkan masalah dan mengambil keputusan secara objektif dan mandiri, mengembangkan kemampuan berpikir kritis,analitis serta mengembangkan rasa ingin tahu dan cara berpikir objektif baik secara individual maupun kelompok.

Gulo (2002) menyatakan, bahwa kemampuan yang diperlukan untuk melaksanakan pembelajaran inkuiri adalah keperluan pendidikan dan pembelajaran (Daryanto, 2010: 68). Inkuiri juga didefinisikan sebagai usaha mencari kebenaran, informasi, atau pengetahuan dengan bertanya. Proses inkuiri memulai dengan mengumpulkan informasi dan data dengan melibatkan panca indera seperti melihat, mendengar, menyentuh, merasakan dan mencium. Sistem pendidikan tradisional telah terlaksana dengan cara menghilangkan semangat proses alami dari inkuiri.Dalam pembelajaran tradisional siswa cenderung pasif dan jarang mengajukan pertanyaan, Siswa hanya mendengar dan mengulang jawaban yang diharapkan.

\section{METODE PENELITIAN}

Populasi dalam penelitian ini adalah seluruh siswa kelas VIII SMP 1 Negeri Lima Puluh yang berjumlah 7 kelas. Sampel dalam penelitian ini terdiri dari dua kelas yaitu kelas VIII-F sebagai kelas eksperimen dan kelas VIII-G sebagai kelas kontrol yang diambil secara cluster random sampling.

Untuk mengetahui hasil belajar fisika siswa dilakukan dengan memberikan tes hasil belajar pada kedua kelas sebelum dan sesudah diberikan perlakuan. Desain penelitian yang digunakan desain penelitian two groups (pretest dan postest).

Data yang diperoleh ditabulasikan kemudian dicari rataratanya. Sebelum dilakukan analisis data, terlebih dahulu ditentukan nilai masing-masing kelompok sampel lalu dilakukan pengolahan data dengan langkah-langkah sebagai berikut yakni; menghitung nilai rata-rata dan simpangan baku, uji normalitas menggunakan uji Lilliefors, uji homogenitas menggunakan uji $\mathrm{F}$, pengujian kesamaan rata-rata pretes menggunakan uji t dua pihak dan pengujian hipotesis menggunakan uji t satu pihak pada data postes. 


\section{HASIL PENELITIAN}

Penelitian ini merupakan penelitian quasi eksperiment yang melibatkan dua kelas yang diberi perlakuan berbeda. Masing-masing kelas terdiri dari 31 siswa. Adapun nilai rata-rata pretes kelas eksperimen 4,22 dan kelas kontrol 4,97. Hasil pretes kedua kelas secara rinci dapat ditunjukkan pada Gambar 1.

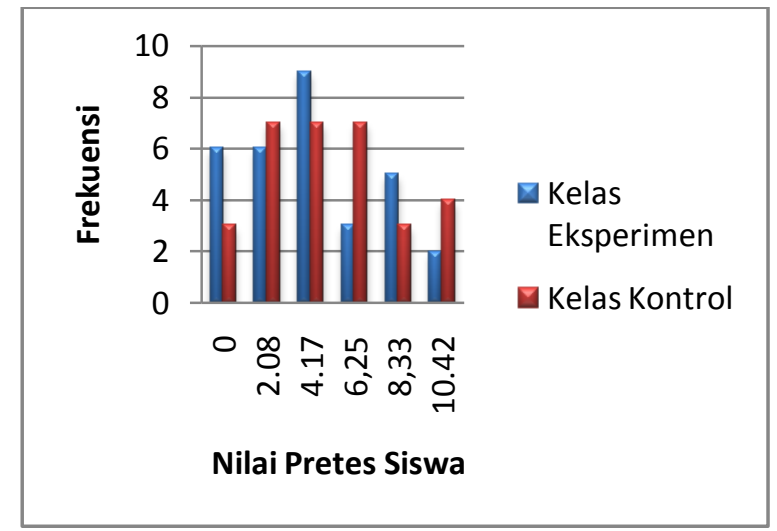

Gambar 1. Diagram batang data pretes kelas eksperimen dan kelas kontrol

Kriteria uji normalitas adalah apabila $\mathrm{L}_{\text {hitung }}<\mathrm{L}_{\text {tabel }}$ dengan $\alpha=0,05$ dapat diartikan data berdistribusi normal. Berdasarkan hasil uji normalitas dengan uji Lilliefors data pretes menunjukkan bahwa pada kelas eksperimen $0,1575<0,1591$ dan kelas kontrol $0,1515<0,1591$. Sehingga dapat diartikan bahwa data hasil pretes berdistribusi normal. Uji homogenitas menggunakan uji $\mathrm{F}$ untuk data pretes diperoleh bahwa $\mathrm{F}_{\text {hitung }}<\mathrm{F}_{\text {tabel }}$ yaitu $1,023<1,84$ dengan $\alpha=0,10$, maka diartikan bahwa data pretes homogen. Setelah data normal dan homogen maka dapat dilakukan uji kesamaan rata-rata menggunakan uji t dua pihak. Berdasarkan hasil hasil uji t dua pihak didapat bahwa kemampuan awal siswa sama. Maka penulis memberikan perlakuan yang berbeda di mana pada kelas eksperimen diberikan pembelajaran dengan menggunakan model pembelajaran inkuri sedangkan pada kelas kontrol diberikan pembelajaran langsung. Setelah itu, diberikan postes. Nilai rata-rata postes untuk kedua kelas tersebut setelah diberi perlakuan yaitu untuk kelas eksperimen sebesar 66,80 sedangkan kelas kontrol sebesar 45,45. Hasil pretes kedua kelas secara rinci dapat ditunjukkan pada Gambar 2. Kemampuan siswa pada kelas eksperimen mengalami peningkatan. Hal ini dapat dilihat dari nilai ratarata siswa pada pretes 4,22 menjadi 66,80 pada saat postes. Sedangkan pada kelas kontrol pada saat pretes nilai siswa 4,97 menjadi 45,45 saat pemberian perlakuan pada akhir pembelajaran yaitu postes.

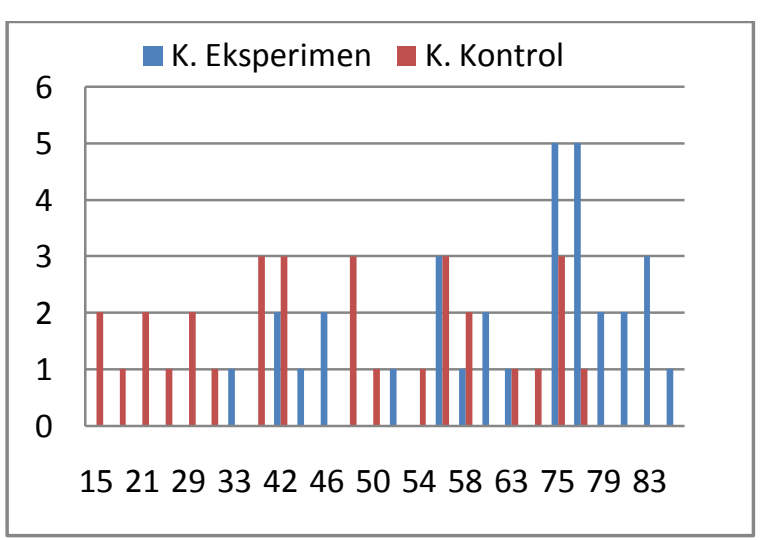

Gambar 2. Diagram batang data postes kelas eksperimen dan kelas kontrol

Hasil uji normalitas data postes diperoleh bahwa $\mathrm{L}_{\text {hitung }}<\mathrm{L}_{\text {tabel }}$ yaitu $0,1282<0,1591$ untuk kelas eksperimen dan 0,0926 <0,1591 untuk kelas kontrol. Sehingga dapat diartikan bahwa data hasil postes berdistribusi normal.

Uji hipotesis menggunakan uji t satu pihak dimaksudkan untuk mengetahui adanya pengaruh yang signifikan dari penerapan model 
pembelajaran inkuiri terhadap hasil belajar siswa. Syarat dilakukannya uji $t$ adalah data harus berdistribusi normal dan berasal dari populasi yang homogen. Setelah kedua syarat terpenuhi, maka pengujian hipotesis data postes dilakukan menggunakan uji $t$ satu pihak dengan $a=0,05$. Berdasarkan hasil perhitungan diperoleh $t_{\text {hitung }}>t_{\text {tabel }}=4,70>1,67$ sehingga dapat disimpulkan bahwa ada pengaruh yang signifikan dari penerapan model pembelajaran inkuiri terhadap hasil belajar siswa pada materi getaran dan gelombang.

Hasil observasi aktivitas siswa kelas eksperimen yang diajarkan menggunakan model pembelajaran inkuiri mengalami peningkatan selama, yaitu mulai dari 50,29 (kurang aktif) pada pertemuan pertama, 69,61\% (aktif) pada pertemuan kedua dan menjadi $90,22 \%$ (sangat aktif) pada pertemuan ketiga.

\section{PEMBAHASAN}

Hasil penelitian menunjukkan bahwa ada pengaruh penerapan model pembelajaran Inkuiri untuk meningkatkan hasil belajar fisika siswa pada materi pokok getaran dan gelombang di Kelas VIII SMP Negeri 1 Lima Puluh.Pada kelas eksperimen diperoleh hasil belajar dengan rata-rata 66,80 berbeda dengan rata-rata kelas kontrol yang hanya mendapat rata-rata kelas 45,43.Analisis uju $\mathrm{t}$ satu pihak mendapat nilai $t$ hit $=4,70$ sedangkan $\mathrm{t}$ tabel=1,67.Dengan demikian $\mathrm{t}$ hit $>\mathrm{t}$ tabel sehingga Ha diterima dan $\mathrm{Ho}$ ditolak, hal ini berarti ada pengaruh yang signifikan dari penerapan model pembelajaran inkuiri terhadap hasil belajar fisika siswa pada materi pokok getaran dan gelombang di

\section{Kelas VIII SMP Negeri 1 Lima Puluh}

Berdasarkan data nilai pretest dan postest beserta nilai aktivitas belajar siswa pada kelas eksperimen diperoleh bahwa siswa yang memiliki kriteria pretes sangat kurang, kriteria aktivitas aktif dan kriteria postes baik (SKAB) berjumlah 12 siswa (38,7\%); siswa yang memiliki kriteria pretes sangat kurang, kriteria aktivitas aktif dan kriteria postes cukup (SKAC) berjumlah 4 siswa $(12,9 \%)$; siswa yang memiliki kriteria pretes sangat kurang, kriteria aktivitas aktif dan kriteria postes kurang (SKAK) berjumlah 1 siswa $(3,2 \%)$; siswa yang memiliki kriteria pretes sangat kurang, kriteria aktivitas cukup aktif dan kriteria postes baik (SKCAB) berjumlah 6 siswa (19,35\%); siswa yang memiliki kriteria pretes sangat kurang, kriteria aktivitas aktif dan kriteria postes baik (SKCAC) berjumlah 3 siswa (9,67\%); dan siswa yang memiliki kriteria pretes sangat kurang, kriteria aktivitas cukup aktif dan kriteria postes kurang (SKCAK) berjumlah 5 siswa $(16,1 \%)$.

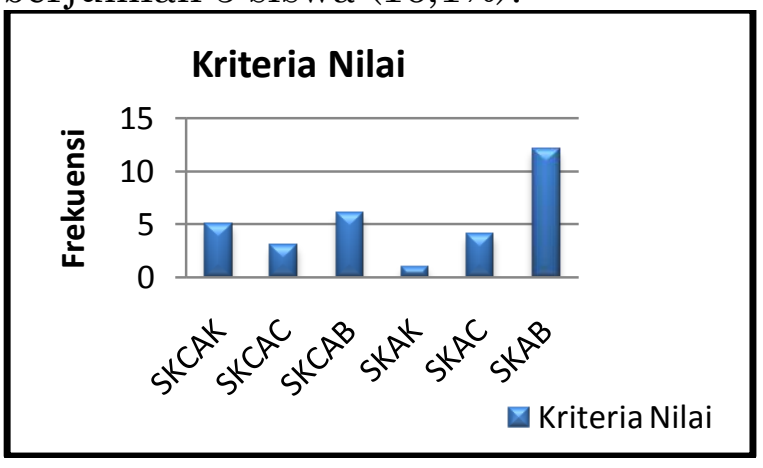

Gambar 3. Diagram batang kategori nilai pretes, aktivitas dan postes

Berikut ini ditampilkan grafik hubungan antara nilai pretes, nilai aktivitas dan nilai postes siswa pada kelas eksperimen yang disusun berdasarkan nilai aktivitas terendah ke nilai aktivitas tertinggi. 


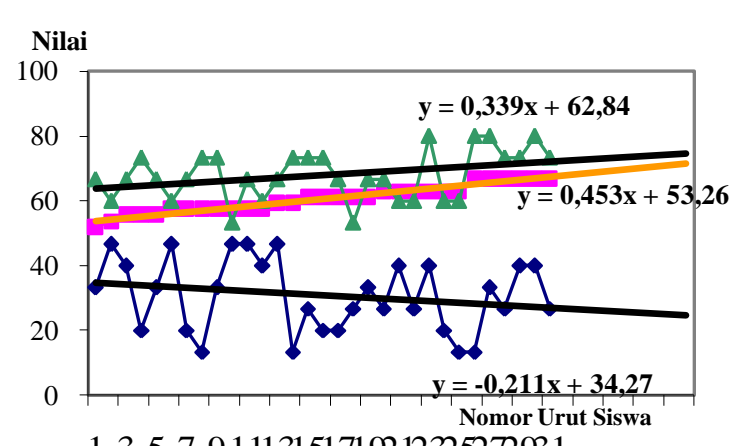
135791113151719212325272931

$\multimap$ Pretest

$\rightarrow$ Aktivitas

Gambar 4. Grafik hubungan nilai pretes, aktivitas dan postes siswa pada kelas eksperimen berdasarkan urutan nilai aktivitas terendah ke tertinggi

Grafik pada gambar 4 diperoleh dengan menggunakan program Microsoft Office Exel 2007. Persamaan linier $\mathrm{y}=\mathrm{ax}+\mathrm{b}$ memiliki nilai a yang menyatakan kemiringan garis. Jika dilihat dari grafik, nilai a pada $\mathrm{y}_{\text {post }}=0.339 \mathrm{x}+62,84$ lebih besar dibandingkan dengan nilai a pada $\mathrm{y}_{\text {pre }}=-0.211 \mathrm{x}+34,27$. Nilai a pada persamaan linier pretes (apre) menjadi acuan kriteria dalam menentukan berpengaruh atau tidaknya nilai aktivitas. Adapun kriterianya adalah sebagai berikut : $a_{\text {post }}>a_{\text {pre }}:$ nilai aktivitas mempengaruhi hasil belajar (nilai postes)

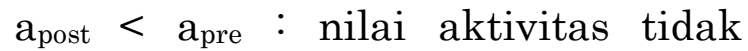
mempengaruhi hasil belajar (nilai postes)

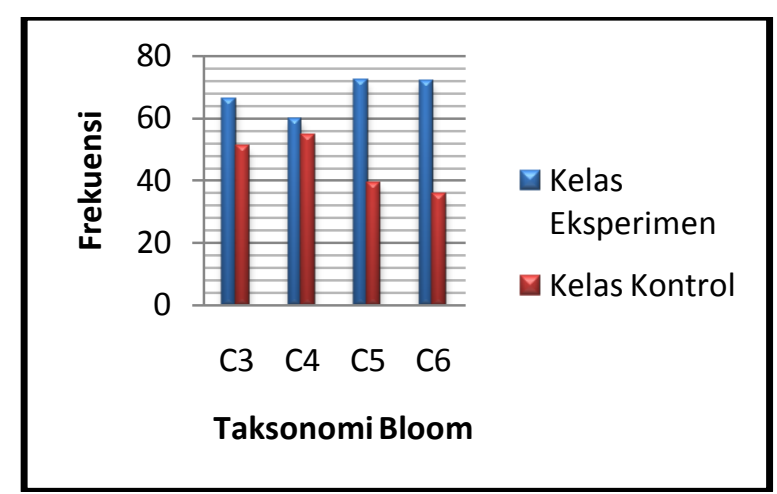

Gambar 5. Diagram batang diagram batang taksonomi bloom

Pelaksanaan model pembelajaran dikatakan berhasil apabila nilai a postes minimal sama dengan nilai a pretes. Namun tidak demikian pada penelitian ini. Hal ini dapat terjadi karena kelemahan peneliti dalam pembagian kelompok. Agar aktivitas kelompok berpengaruh terhadap hasil belajar disarankan agar membuat perencanaan yang lebih baik pada pengorganisasian kelompok. Dalam penelitian ini kelebihan yang dapat diberikan dengan menggunakan model pembelajaran inkuiri adalah meningkatkan kemampuan siswa dalam pemecahan masalah dan menjadi pebelajar yang otonom dan mandiri. Walaupun penggunaan model pembelajaran Inkuiri dapat meningkatkan hasil belajar dan aktivitas siswa, tetapi selama pembelajaran masih ada kendala yang dihadapi peneliti yang menyebabkan pencapaian hasil belajar belum maksimal yaitu masih terdapatnya beberapa siswa yang kurang berpartisipasi dalam mengeluarkan pendapat, masih mengandalkan teman-temannya yang aktif. Oleh sebab itu upaya yang dilakukan adalah agar guru menberikan penjelasan dan arahan 
supaya semua siswa ikut berpartisipasi.

Dalam pembelajaran dengan penerapan model inkuiri ini siswa akan dihadapkan pada suatu permasalahan yang harus diamati,dipelajari,dan dicermati yang pada akhirnya dapat meningkatkan pemahaman konsep fisika. Dalam kegiatan pembelajaran inkuiri apabila siswa meningkatkan partisipasinya dalam kegiatan pembelajaran, maka dengan sendirinya akan meningkatkan pemahaman konsep materi pembelajaran, pada akhirnya hasil belajar siswa otomatis akan menigkat.

\section{KESIMPULAN DAN SARAN}

\section{Kesimpulan}

Dari hasil penelitian dapat disimpulkan bahwa: Model pembelajaran inkuiri berpengaruh terhadap hasil belajar siswa.

Model pembelajaran inkuiri meningkatkan aktivitas belajar siswa yang dapat diamati dengan peningkatan aktivitas dari pertemuan pertama $(50,29)$, pertemuan kedua $(69,61)$ dan pertemuan ketiga $(90,22)$.

\section{Saran}

Saran kepada peneliti selanjutnya yang ingin meneliti tentang model pembelajaran inkuiri ditinjau dari aktivitas pembelajaran belum ada siswa yang maksimal mencerminkan aktivitas model inkuiri . bagi peneliti atau guru selanjutnya hendaknya memperbaiki indikator yang ada dalam sintak yang belum maksimal yaitu menjawab pertanyaan yang diajukan, mengajukan pertanyaan, mencatat data hasil percobaan, menjelaskan hasil diskusi dan menentukan pertanyaan yang efektif
DAFTAR PUSTAKA

Arikunto, S, 2011, Dasar-Dasar Evaluasi Pendidikan,

Penerbit, Bumi Aksara.

Gulo,W Harahap, R .2011. Pengaruh Inqury Training Model

Terhadap Hasil Belajar Siswa Pada Materi Pokok Zat

Dan Wujudnya Di Kelas VII SMP Negeri 6 Medan T.P 2010/2011. Skripsi. Medan : FMIPA Unimed .

Istarani,2011, $58 \quad$ Model Pembelajaran Inovatif, Medan, Penerbit, Media Persada.

Joyce, B., dan Weil, M., (1996), Models of Teaching, Prentice Hall, USA

Krisno, A dkk.2008. IPA Fisika SMP dan MTs untuk kelas VIII, Pusat Perbukuan Depertemen Pendidikan Nasional, Jakarta.

Rustiniini,Tin.2009. Penerapan model inkuiri dalam meningkatkan pembelajaran ips di kelas IV sekolah dasar. Skripsi. Medan : FMIPA Unimed.

Sanjaya ,W, 2010, Strategi Pembelajaran Berorientasi Standar Proses Pendidikan, Prenada Media Grup, Jakarta.

Sardiman, (2009), Interaksi dan Motivasi Belajar Mengajar, Penerbit, PT Raja Grafindo Persada.

Sirait ,R .2010. Pengaruh Inqury Training Model Terhadap Hasil Belajar Siswa Pada Materi Pokok Zat Dan Wujudnya Di Kelas VII SMP Negeri 1 Batang Kuis T.P 2009/2010. Skripsi. Medan : FMIPA Unimed .

Sudjana, (2002), Metode Statistik, Penerbit Tarsito, Bandung. 
Trianto. 2010. Mendesain Model Pembelajaran Inovatif Progresif. Jakarta : Kencana Prenada Group.

Zainuddin. 2008. Penerapan metode inquiry berbasis kelas dalam pembelajaran struktur atom. Skripsi. Medan : FMIPA Unimed. 